\title{
EXTRATO BACTERIANO ASSOCIADO À IMUNOTERAPIA PARA ÁCAROS EM CRIANÇAS COM DERMATITE ATÓPICA
}

\section{Pôster}

Autores deste trabalho:

Helena Abelha Stremlow: IAMSPE

Debora Mutti De Almeida Monteiro: IAMSPE

Dina Larissa Da Silveira Capelasso: IAMSPE

Ana Luisa Barbosa Belarmino: IAMSPE

Daniandra Figueiredo De Morais: IAMSPE

Gabriela Aline Andrade Oliveira: IAMSPE

Veridiana Aun Rufino Pereira: IAMSPE

Andrea Pescadinha De Carvalho

Área do Trabalho: Pediatria

Data da submissão :15/08/2018 às 18:34

\section{Justificativa}

A pele do paciente com dermatite atópica (DA) é mais susceptível a infecções ou colonizações por microrganismos, tais como o Staphyloccocus aureus, capaz de produzir toxinas com propriedades de super antígenos, o que determina a proliferação de células $T$ e estimula os queratinócitos a liberar citocinas pró inflamatórias, cronificando a inflamação.

\section{Objetivo(s)}

Avaliar a evolução clínica e o perfil epidemiológico dos pacientes com DA submetidos à imunoterapia subcutânea alérgeno-específica (ITSC) associada a extrato bacteriano contendo S. aureus.

\section{Método(s)}

Estudo retrospectivo com análise de prontuários de crianças com DA moderada/grave, classificadas de acordo com o SCORAD (\&\#8805;25), com teste cutâneo e/ou IgE específica positiva para Blomia tropicalis (BT) e Dermatophagoides pteronyssinus (DP), selecionados, assim, para realizar ITSC alérgeno-específica, em associação com o extrato bacteriano.

\section{Resultado(s)}

Foram incluídos 19 pacientes, com predomínio do gênero feminino (78,9\%). A idade dos pacientes variou entre 3 e 18 anos, sendo a média da idade 11,7 e prevalência maior em crianças entre 5 e 10 anos (42,1\%). A maioria dos indivíduos referiu início das lesões entre 0 a 2 anos (47,3\%). O nível sérico de IgE total foi maior que 1000 $\mathrm{UI} / \mathrm{ml}$ em $63 \%$ dos pacientes analisados. A média do nível sérico de IgE específica para DP e BT era de $90,94 \mathrm{UI} / \mathrm{ml}$ e $27,84 \% \mathrm{UI} / \mathrm{ml}$, respectivamente. Antes de iniciar o tratamento com imunoterapia, a média do SCORAD destes pacientes era de 39,8 . Após 3 meses de tratamento, a média do SCORAD foi 25,63, com redução de $30,7 \%$. Nove pacientes completaram 6 meses de tratamento, com média do SCORAD 24,82 
com redução de $42,22 \%$. Todos os pacientes continuam em tratamento, com reavaliação a cada três meses

\section{Conclusão (ões)}

Os pacientes analisados apresentaram alta positividade para DP e Blomia e elevado valor de IgE. A avaliação dos pacientes com DA moderada/grave submetidos a tratamento com a ITSC para ácaros associada a extrato bacteriano mostrou redução importante (\%) do SCORAD após 6 meses. 